\title{
TOLERANCE BOUNDARIES AND CULTURAL EGALITARIANISM
}

\author{
Saulius Kanišauskas \\ Mykolas Romeris University, Departament of Philosophy, \\ Ateities g. 20, LT-08303 Vilnius, Lithuania \\ E-mail: sauliusk@ml.It
}

\begin{abstract}
The significance of formal criteria which could help to sort out the problem of tolerance paradox has emerged in the background of cultural egalitarianism. Alas, such criteria have not been established so far. The conviction that the problem of tolerance is significant just in the context of social and political discourse might be questioned due to the fact that this attitude did not help to tackle this problem throughout the last centuries. The paper aims to show that the problem of tolerance can be solved taking into account systemic attitude and synergetic insights. The current study into the literature on tolerance concludes that the formal criterion, which defines the tolerance boundaries in the most general sense, is considered to be such deviations from the standard (as ideal parameters of social system) when tolerance can function normally (stably). Cultural egalitarianism, which requires equalizing the rights of the majority and the minorities facing discrimination, impinges on the ratio of necessary diversity, and thus has to be questioned.
\end{abstract}

Keywords: egalitarianism, constant of requisite disharmony, tolerance boundaries, tolerance paradox.

doi:10.3846/limes.2010.07

\section{Introduction}

At the dawn of the new millennium (on 6-9 September 2000), the United Nations General Assembly adopted United Nations Millennium Declaration, which encourages people and governments of the world to promote creation of peace culture based on tolerance and respect to each other. Different declarations, however, may just remain an expression of good will and strivings. Neither the number of war and political conflicts has decreased, nor tolerance increased. Alas, new serious problems of tolerance and discrimination have emerged. For instance, BNS agency has presented information, concerning political scandal which was caused by Rocco Buttinglione, the Italian politician nominated to the post of Justice Minister of the European Union (EU), who said that "children who have just mother but not father are the children of mother who is not very good" (Lietuvos žinios, 18 October, 2004, Issue 242). The reaction to this assertion was immediate (as well as to his previous statement that homosexuality is a sin) - the Italian politician's nomination was not only derailed but also he was evaluated as the embodiment of intolerance.

This political conflict is symptomatic: the politicians of the EU who declare tolerance towards diversity of beliefs turned out to be extremely intolerant towards the 
Catholic attitude to family. It cuts both ways: having accused the Italian Catholic politician of intolerance towards single mothers and sexual minorities, they demonstrated their intolerance towards intolerance.

This recurrent phenomenon is closely related to the paradox of intolerance and to the attempt of modern liberalism to exercise cultural egalitarianism (when the rights of the majority and minorities are being equalized). The tendency of cultural egalitarianism has already reached Lithuania. The media abounds in extensive discussions on the newly adopted law by the Lithuanian Parliament (Seimas) on Protection of Minors against the Detrimental Effect of Public Information (Valstybès žinios, 2009 Issue: 86-3637). Both the proponents of traditional values and their opponents accuse each other of being intolerant. It appears utterly impossible to envisage logic and understanding of tolerance essence behind these emotional accusations. Thus, the relevance of tolerance problem is indubitable. Although the tolerance boundaries have been discussed for centuries, they have not been adequately and clearly defined even in theoretical works (which, however, do not distinguish in being abundant, especially in Lithuania).

This paper aims at answering two questions: a) Is it possible to propose such definition of tolerance boundaries which could be reasonably objective (intersubjective)? b) Is cultural egalitarianism truly useful to society? The widely spread belief that the problem of tolerance is significant just in the contexts of social and political discourse was one more underlying reason to resume writing this paper. Thus, the paper sets out to show that another point of view is possible, and the latter objective is accomplished through scientific literature exploration employing neoreductionist methodology.

\section{The conception of tolerance as a social and political phenomenon}

The most general meaning of the word tolerance is willingness to accept anything what is not acceptable to a person or social groups (to accept various opinions, attitudes or behaviour, i.e. the otherness, that you may not agree with and what is evaluated negatively). The origin of this word is from the Old Greek word talao, which means endure, survive while the word tolerantia means patience. Tolerance is also perceived as a voluntary decision not to oppose and endure what is evaluated as being negative (Plečkaitis 1998: 7, 47), or resignation with attitudes which we do not like or even think them being harmful (Legutko 2006: 7).

Catriona McKinnon (McKinnon 2006: 14-15) presents six structural features of tolerance which, as she points out, most theorists basically agree with:

1. Difference: what is tolerated differs from the tolerator's conception of what should be done, valued, or believed;

2. Importance: what is tolerated by the tolerator is not trivial to her;

3. Opposition: the tolerator disapproves of and/or dislikes what she tolerates and is ipso facto disposed to act so as to alter or suppress what is tolerated;

4. Power: the tolerator believes herself to have the power to alter or suppress what is tolerated; 
5. Non-rejection: the tolerator does not exercise this power;

6. Requirement: toleration is right and/or expedient, and the tolerator is virtuous, and/or just, and/or prudent.

The author maintains that tolerance is possible just in case when a situation can be described using the first four features of tolerance. Moreover, she differentiates between two interpretations of a person who is supposed to be tolerant - the weak and the strong. The basic difference between the two interpretations lies in the fact that the first one implies intolerance as a possibility to create conditions for tolerance while the latter rejects that; therefore, the weak interpretation may give rise to further restrictions of tolerance (McKinnon 2006: 18-27).

According to Andrew Fiala (Fiala 2005: 1-2), the Western culture comprehends tolerance as a certain political principle, whereas in the earlier times the ancient Greeks, for instance, associated tolerance just with an individual's ethical life. And yet, current political discourse puts great emphasis on the integration of marginalized minorities into society but not on the problem of their toleration. However, the process of integration is impossible without tolerance.

If we comprehend tolerance as reconciliation with attitudes which we do not justify and even consider them harmful, it might be interpreted as a kind of coercion on ourselves (Spieß 2003). Indeed, it is difficult to make yourself not to react to something that seems inappropriate and even harmful. Is it possible to bring oneself to tolerate violence or slaughter? But it is often tolerated. What I mean is that repressive structures existing in any country or wars are being, however, tolerated. Apparently, Ryszard Legutko must be right claiming that the concept of tolerance has always implied something mysterious and it is not sensible to refer to it in terms of an independent category. Moreover, it cannot be independent since it has always been related to essential moral and political concepts (Legutko 2006: 7-8). Therefore, it is not accidental that John Locke, who proclaimed his famous "Letter on Tolerance" (Laffitte 2009 ) in 1688 , is considered to be the founding father of modern tolerance and liberal ideology. The most prominent theorist of new liberalism John Rawls did not attempt to hide that his theory of justice as fairness is nothing more that Locke's theory of social agreement just being raised to a higher degree of abstraction (Baranova 2004: 280). Rawls' conviction that material inequality existing in real societies has to be regulated the way it could serve the people of inferior position has been adopted in the view that moral inequality has also to be regulated. First of all, social and moral discrimination against gender and sexual minorities is implied here. Namely, such discrimination was envisaged in Buttinglione's statements by the EU politicians who grounded their indignation on new liberalism. The new liberal practice might be interpreted as follows: single mothers and homosexuals are regarded to be in inferior position, thus it is necessary to safeguard their rights. This practice and its theoretical assumptions were accurately described by Algirdas Degutis: "If we allow the rights of minorities to penetrate our society, they will devour the usual freedoms of people. [...] Despite the country's 'equal' care of everyone's interests [...], having acknowledged 
the rights of discriminated minorities, it (the country) has to enforce aggressive discriminatory policy towards the society" (Degutis 2009).

This "discriminatory struggle against discrimination", as Degutis qualified destructive antagonism of liberal tolerance towards traditional values, is closely related to the so called paradox of tolerance: if we logically develop the theory of cultural egalitarianism (the equalization of the majority and minority rights), we give rise to inevitable controversies. Due to its consistent development, "liberal emancipation" seems to be completed just when human rights are equalized to the rights of worms or minerals (Degutis 2009).

\section{The problem of tolerance boundaries}

The tolerance paradox implies an idea that unlimited tolerance contradicts itself, thus it has to be bounded (Plečkaitis 1998: 186), i.e. we have to be intolerant to some expressions of tolerance. According to Legutko, who studied the history of tolerance, this idea was fully grasped by the first participants in the argument on tolerance. Even Locke, who disseminated the necessity of tolerance, understood that even cognitive egalitarianism is impossible (Legutko 2006: 111-112). Therefore, he accepted the idea that the object of tolerance is just "neutral things", and it was decided that tolerance is not related to what is morally bad, harmful or villainous, thus we can argue just about what is in the "middle" (Legutko 2006: 24).

This agreement has not, however, solved the problem because we always question what is good or bad, useful or harmful. Since Socrates' times up to now, moral philosophers have been arguing about the basic notions of morality (see Baranova 2004). The problem of tolerance is not only political problem but also the problem of moral philosophy. This is due to the fact that the morality paradox, as Legutko points out, possesses two aspects: the principle of tolerance starts contradicting both political principle, which requires to adopt more general attitudes and neutralize the phenomena that may pose danger to the oneness of society, and intellectual principle, which demands to seek what is good and right (Legutko 2006: 7).

Taking into account that Rawls considered political philosophy inherent in moral philosophy (Miniotaite 1988), it becomes evident that both principles are interrelated, thus in the context of the tolerance paradox this correlation could be named as the ratio problem of mercy (tolerance) and being principled (intolerance), which sometimes is called as the problem of intolerance to intolerance (Sprindžiūnas 2004). The above mentioned intolerant evaluation of Rocco Buttinglione's intolerance is a classical example illustrating this phenomenon. It may be related to applying double standards to evaluation of the same phenomena, i.e. moral relativism. Intolerance towards intole-rance of others becomes tolerance towards your own intolerance. Different political attitudes which are distanced from moral decisions and legitimized by lobbying activities become ultimately decisive.

Usually it is emphasized that we can trace philosophical roots of intolerance in Plato's The State (Fiala 2005: 177), that we cannot discuss the problem of intolerance separately from other fundamental philosophical problems (Legutko 2006: 8), that 
this problem is primarily related to axiological problems (Plečkaitis 1998: 82) and that we can discuss the problem just at the level of conscience but not of cognition (Spieß 2003). Jürgen Spieß illustrates the latter claim by saying that there are some people who believe that two plus three is six. However, he doubts whether we appear tolerant if we allow such people to build bridges and buildings. Furthermore, he questions the essence of tolerance if we do not say that a person is wrong. A similar position is maintained by McKinnon (McKinnon 2006: 9), who claims that tolerance is by no means incompatible with a belief that making two plus two equals five. This view can be paraphrased in the following way: there and then, where and when a clear and precise decision is necessary, it is impossible to speak about tolerance towards mistakes and fallacies. This idea will be discussed further since it tends to be true just under certain conditions.

While summarizing the study of tolerance concept, Legutko (Legutko 2006: 244245) concludes that nowadays the tolerance concept has little to do with the processes of forming social peace, whereas contemporary philosophers and politicians tend to focus on the autonomy of an individual and pluralism of values in the first place; thus making them the basis of social order and peace. Hence, the tolerance paradox of tolerance remains not taken into consideration. According to Romanas Plečkaitis (Plečkaitis 1998: 200), this happens due to the fact that theoretically the problem of establishing the tolerance boundaries is not so complex since we have documented human rights and we share universal values. To make it more understandable, it seems that the paradox of tolerance is often ignored just because the tolerance boundaries have been precisely defined in international declarations (e.g. Human Rights), conventions and laws.

However, we can hardly consider documented human rights as a theory; it is rather a general political agreement. Apparently, we can doubt the existence of universal values, i.e. we can doubt if these values are acknowledged and willingly accepted by all people. The pluralism of values is increasingly becoming the only value in modern society.

Despite this, I believe that such universal values still exist. Many great thinkers referred to them throughout the centuries. Although their gradations of values differ somewhat, all of them underline that orientation to them gives meaning and value to the human entity. I argue that only the orientation to the highest values conveys genuine sense of tolerance. Yet, some people think that such belief is speculative; rather, it is more an expression of feelings than reason. Thus, the problem of tolerance boundaries will be further explored by offering rational arguments.

\section{The ways to formalize the tolerance boundaries}

Plečkaitis (Plečkaitis 1998: 72-90) presents six ways of tolerance reasoning: pseudoreasoning, ontic and cognitive, axiological, biological, logical and social. Although each of them, excluding the first one, has its own pros and cons, neither of them can explain the paradox of tolerance. In order to solve it, Plečkaitis (Plečkaitis 1998: 251-257) 
suggests that the principle of tolerance is best explored by employing the tools of limited logical formalization. This method implies the reduction of notions used in the humanities and social sciences into abstract symbols and their further logical analysis.

In addition to logical formalization, there are other ways to solve the tolerance paradox. Also, mathematical formalization (mathematical modelling) can be employed and is employed. Although the application of mathematical models in social sciences became possible just after high-powered computers were created and when it was realized that social processes are possible to describe using non linear equations, nowadays some other results were achieved as well. For instance, mathematical models are employed to describe not only the development of political parties (Pyragas 2003: 6062) but also a well known love story of Romeo and Juliet (Pyragas 2003: 143-145).

Highly abstract synergetic methods are encroaching on such subtle spheres of life as human psyche. A perfect example of it is a work devoted to general and social psychology where you will not find anything except solutions of mathematical equations and conclusions (Мированов 2005).

Nevertheless, the intervention of natural and mathematical sciences into the humanities and social sciences is being questioned by both the humanity scholars and natural scientists. The concept of tolerance first correlates with human relations, evaluations, moral attitudes; thus it is assumed that we can discuss tolerance just at the level of conscience but not of cognition. In terms of science philosophy, there is a belief that to reduce the problems of tolerance to natural science cognition is not only meaningless but also impossible, whereas in terms of moral philosophy, there is a belief that if we do that, we commit a naturalistic fallacy. Therefore, even tentative attempts to view the problems of the humanities and social sciences from the natural science positions encou-nter substantial resistance or more often they are ignored.

Yet, the extreme positions of antireductionists have been decreasing due to the fact that a new type of reductionism called neoreductionism (Kanišauskas 2003: 149-150) has emerged lately. It comprises two ideas: a) the whole consists of reciprocally interrelating parts which produce new qualities and which in turn are not reduced in the former qualities but they are described by universal laws (John T. Werle); b) we can reduce theories but not the laws or their conclusions (L. G. Bazhenov).

The first serious step towards the unification of the humanities and social sciences (or at least dissolving their basic contradictions) is considered Ludwig von Bertalaffy's General System Theory (GST) published in 1968. It focuses on the ratio between the whole and part, system structures and functions, their environment and development, and, finally, the interaction between the systems and their elements (Seppanen 1998: 191-196). Von Bertalaffy maintained that despite their significant achievements, neither physics nor chemistry or biology is able to account for the phenomenon of life and mind, even if they conflated their researches and achievements into the whole (an antireductionist attitude). But if we realized that the whole combined of elements means something more than just a sum these elements, we could trespass the boundaries which differentiate between "the inanimate" and animate nature (a reductionist attitude). GST was successfully developed by Mihajlo D. Mesarović who formulated the notion of hierarchically subordinated systems and showed that the system 
hierarchy occurs either because of interactions of homogeneous or heterogeneous system components or during the process of dynamic self-organization (Sepannen 1998: 196-197).

The term of self-organization was first introduced by a British engineer and one of the founding fathers of cybernetics W. Ross Ashby in 1947. Although the law called by his name will be discussed further, it is felt necessary to underline that the basic principles of cybernetics (as well as GST) were introduced into synergetics which is sometimes identified with the theory of self-organization, related to the theories of catastrophes, chaos, fractals and autopoiesis while in the USA it is known under the name of complexity theory. Since the fundamentals of synergetics and its implied principles were discussed earlier (Kanišauskas 2008), here just the issues important to establishing the tolerance boundaries are explored.

Although the above mentioned Werle's neoreductionist attitude is primarily based on GST statement that it is impossible to know the whole if we do not know its elements (a reductionist attitude), it is necessary to realize that due to the interaction of elements forming the whole, the whole is basically (qualitatively) differs not only from its separate elements but also from their arithmetic sum (an antireductionist attitude). The possibility to explore the whole which is qualitatively different from its constituent elements lies in the possibility (taking into account the subordination "rules" of hierarchical structures) to explore essential interactions of elements forming the whole. Though it is impossible to thoroughly explore all interactions of system elements because of abundance of elements and relations, the phenomenon of modelocking observed in synergetics allows detecting such system elements which become non-abundant management parameters, which in their turn determine the emergent formation of new qualities and hierarchical levels (Kanišauskas 2008: 78-100).

The subordination "rules" of hierarchical structures are rather simple: a) every higher hierarchical structure is energetically supported by the lower; b) every higher hierarchical structure influences, directs and manages the actions of the lower; c) a system as the whole determines the action of all its elements. The latter idea developed in neurophysiology was called downward causation (Hulswit 2005). In physics, it is known as Mach's principle.

It is of utmost importance to note that management parameters are closely connected with topological organization of systems which is the same as information about the basic system structures (Kanišauskas 2008: 84) or, as Margaret J. Wheatley pointed out, "an organization of immaterial power" (Wheatley 1999: 54). Thus, even inanimate complex systems are managed not by harsh physical power but by informational processes. This helps to render one of the most fundamental propositions of synergetics which allows bridging the spheres of the humanities and social sciences and which allows reducing the natural science theories to the spheres of the humanities and social sciences (neoreductionism). Cross-disciplinary approach which emerged at the end of the 20th century implies active interaction of different scientific approaches due to which other forms (every day, religious, esoteric, etc) of rational experience occurred (Киященко 2005), and all this has to be treated as an outcome of neo-reductionist attitudes. 
The fact that neoreductionist attitudes have been actively penetrating into life may be supported by an increasing number of publications in the humanities and social sciences (Allen 2006; Chia 2006; Cilliers 2005; MacIntosh et al. 2005; Hesse-Biber, Leavy 2006; Ельчанов 2005; Хиценко 2005). This gives hope to solve the problem of tolerance boundaries applying neoreductionist methodology, more precisely, rather formal methods of socio-synergetics. Socio-synergetics or social synergetics is a newly coined term implying the importance of penetration of synergetic methods, laws and thinking into social sciences. It is being taught at some universities in Russia (Ельчанов 2005).

\section{Tolerance boundaries in the view of socio-synergetics}

To establish a formal criterion which allows defining the tolerance is possible just in case we find the most essential idea implied in the usage of this concept. Taking into consideration that the concept of tolerance is first of all associated with individuals and their groups' mutual relations and values, we should not forget that intellectual and material artefacts and the organism's tolerance to physical and mental interventions are evaluated (at the same time, they are tolerated or not tolerated). Although there is a view that in these cases the concept of tolerance is used as metaphor and thus we cannot apply such usage to human relations, it was proved earlier (Lakoff, Johnson 1999) that all abstract conceptions and terms used in science and philosophy are metaphorical in their nature. Moreover, metaphor being the product of thinking provides in-depth understanding of differrent concepts. Hence, the search of figurative meanings in tolerance concept is advantageous in human relations analysis.

As a medical term, the word tolerance implies the ability to tolerate different medicine dosages, suffer pain, difficult conditions without being harmed. As a financial term, it indicates inevitable allowed digression of coin weight from the established parameters defined by the law. In logic and science methodology, tolerance is defined as a methodological principle which emphasizes a possibility to express problems in different logical systems and recommends using conventions instead of prohibitions (Plečkaitis 1998: 7-10). In technical and other measurements, tolerance is viewed as the amount by which the measurement of a value can vary without causing problems; the less the tolerance, the more reliable, accurate the equipment or product is. The latter understanding of tolerance is explicated into the tolerance of dimension and form, though both of them are primarily based on the requirement to compare the ideal dimensions or forms with allowed digressions (Žuravliovas 1980).

From the analysis of the mentioned concepts of tolerance, it becomes obvious that all of them imply the notion of tolerance boundaries as a norm or moderation. Apparently, it becomes the most distinguishing in technical measurements: only these deviations from ideal parameters of each system can be tolerated which do not interfere with normal (stable) functioning of this system.

This view incorporates two significant aspects: a) neither in theory nor in practice, ideal precision and system functioning is possible, thus we have to tolerate deviations 
from norms which are perceived as ideal parameters of a system; b) however, we can tolerate only those deviations which do not interfere with normal (stable) functioning of this system.

This understanding of the concept of tolerance is rather universal and it tends to reveal the essence of it in the most precise way. If we apply it to medicine, psychiatry, immunology, such drugs, physical and mental interventions which are not harmful to the body and mind's stability and which are directed at enhancing stability are considered as being tolerated. If we apply that to the sphere of logics and terminology, such logical constructions and terms which allow stable functioning of logical and linguistic systems are considered as being tolerated. If we apply this abstract concept of tolerance to social, political, moral, religious and ecological spheres, the following issues are being tolerated: a) such social, political systems and ideologies that do not threaten the present social and political stability and harmony of society functioning; b) such moral views and actions inspired by them which do not destroy the existent relations in a family, among relatives or colleagues; c) such religious beliefs which do not violate the prevailing theological and dogmatic system and its harmony; d) such actions which do not destroy the existent ecological systems, their harmony and does not undermine their stability.

Hence, it is obvious that tolerance boundaries can be defined in terms of existent stability and functional harmony of any system (natural, social, the humanities), and this can be considered to be a formal criterion of tolerance boundaries.

This proposition can be undermined by the idea that if we do not tolerate fundamental changes and try to preserve the same status and order, the society might find itself in stagnation. To simplify, if a society strived just to maintain the existent stability, it would stuck in its own development. This definition of tolerance boundaries is in direct contradiction to the famous Ashby's Law of Requisite Variety stating that "Variety absorbs variety". An application of this law to society implies that a society has to be diverse (it is an essential prerequisite for its survival), thus it needs geniuses and lunatics, altruists and egoists, religious and agnostic people, the rich and the poor, heterosexuals and homosexuals, tolerant and intolerant people, etc. The source of reality development consists of oppositions based on variety. Therefore, any boundaries and prohibitions of otherness are at least tentative.

Alas, the latter claim is also questionable since Ashby's law implies the idea of necessary disharmony: a certain disarray and disharmony has to exist in order to maintain variety. It was pointed up by Aleksej A. Davydov, a Russian sociologist working in the sphere of socio-synergetics. Having based his "systemic sociology" on GST and synergetics (Давыдов 2006: 6-8), he refers to the works of the famous American sociologist and Pitirim Sorokin and asserts that social systems are not unique because they obey the same general systemic regularities, and $96 \%$ of our behaviour is determined by self-organizing processes directed at preserving stability. In order to preserve variety and harmony (stability) in a constantly changing society and its relations, a certain disharmony is required. The harmony of social relations is best described by the Fibonacci numbers and "Golden section" which defines prevailing 
proportions in nature. Davydov's calculations based on these proportions indicate that the required disharmony constant, which ensures harmony and variety (the natural development at the same time), is $6 \%$. It means that to ensure the stability of natural and social systems' own development, about $6 \%$ of deviations from its parameters guaranteeing absolute stability is a prerequisite. It is noteworthy that Davydov investigated just these structural and functional parameters of society which are ascribed to the parameters of order or management. Empirical data slightly differ from theory data $(6.33 \%)$ but the tolerated error $(0.498 \%)$ indicates that practically they correspond to the theoretical ones (Давыдов 1994: 126-129). Considerable deviations (to one or another side) of management parameters from necessary disharmony constant indicate not only disorder of stable functioning of social system but also they may become the cause of radical changes or even destroy the whole system.

The necessary prerequisite of a normal society is existence of different minorities, a wide range of different attitudes and behaviour; but if their ratio (relation to the whole) significantly deviates to one or another side from necessary disharmony constant, the society as a system (or its elements) would undergo a threat to be completely destroyed. Thus, the society or individuals (consciously or unconsciously) behave in the way they could preserve dynamic stability and this behaviour can be described as natural. They genuinely resist everything what destroys the harmony of the society in the same way as deviations from this harmony are naturally tolerated. Hence, such natural beha-viour is called as being self-organizing. It is concluded that the tolerance boundaries are likely to be defined by applying the necessary disharmony constant.

\section{Tolerance and cultural egalitarianism}

The view proposed by cultural egalitarianism that it is necessary to equalize the rights of the majority and discriminated minorities seems to be tentative if we refer to the above described notion of tolerance boundaries. However, the view that it is necessary to discuss tolerance in terms of conscience but not knowledge and that the proposition "two plus two equals five" is impossible to tolerate has to be examined first.

On the contrary, the proposition "two plus two equals five" is not only tolerated but it also reveals the essence of non-linear processes (of necessary disharmony at the same time). Qualitative development (to the "better" or "worse" direction) is possible just in case of high degree of instability, whereas the "common sense" does not exist at that time. The butterfly effect occurs when even deteriorating little impact or inner changes may cause a catastrophe. This could result in the earlier mentioned social system deterioration or its transfer to a new development attractor. In other words, it means that if the completely destabilized system does not deteriorate, an inner "mutation" or radical qualitative change occurs within it, and the latter does not have much in common with the previous state. The destabilization norm is defined by the necessary disharmony constant. Although we can be tentative towards its preciseness or its methodological validity, not the numerical meaning of the constant is important but the fact that destabilized norm result in non-linear processes and the logic that "two plus two equals four" becomes irrelevant and everything that existed inevitably 
deteriorates or changes radically. The changes are so radical that they differ significantly from the previous states.

Apparently, it is not the conscience which let us know that the violation of norms is tolerated just within limited boundaries but our innate sense of self-defence. The conscience "operates" within the sphere of tolerance features named by McKinnon, and the sense of self-defence enables us to question what might happen if the rights of sexual minorities were equalled with the rights sexual majority; and due to this, the ratio of sexual minorities and majority would deviate from the necessary disharmony constant. Vegetation is not the way how people breed. Thus, does Buttinglione's concern seem not being worth of attention?

Although this question is rhetorical, we can see deeper implications and an answer to the question whether cultural egalitarianism is useful to the society. The above presented arguments indicate that the requirement to equalize the moral rights of minorities with the rights of majority sounds fairly dangerous because it interferes with the proportions of necessary variety.

\section{Conclusions}

The most general formal criterion defining the tolerance boundaries is the deviations from the norm as ideal system parameters under which the system can continue its normal (stable) functioning. This proposition also applies to social sciences.

Deviations from the norm are a necessary condition of society development and they are defined by necessary disharmony constant. Small deviations from this constant encourage social developmental changes and allow the society to remain relatively stable. Thus, small deviations within tolerance boundaries are both encouraged and necessary.

All behaviour and intentions which encourage large deviations from the constant are considered not tolerated. Cultural egalitarianism ideas are likely to have nothing to do with tolerance because they destroy the foundations of human existence.

\section{References}

Allen, P. M. 2006. "Evolving Complexity in Social Science", in MacIntosh, R.; MacLean, D.; Stacey, R.; Griffin, D. (Eds.). Complexity and Organization: Readings and Conversations. London, New York: Routledge, 134-161.

Baranova, J. 2004. XX amžiaus moralès filosofija: Pokalbis su Kantu. Vilnius: Vilniaus pedagoginio universiteto leidykla.

Chia, R. 2006. "From Complexity Science to Complex Thinking: Organization as Simple Location", in MacIntosh, R.; MacLean, D.; Stacey, R.; Griffin, D. (Eds.). Complexity and Organization: Readings and Conversations. London, New York: Routledge, 210-236.

Cilliers, P. 2005. Complexity and Postmodernism: Understanding Complex Systems. London, New York: Routledge.

Degutis, A. 2009. „Liberaliosios pasaulèžiūros aporijos“, Logos: Religijos, filosofijos, komparatyvistikos ir meno žurnalas 58: 44-53.

Fiala, A. 2005. Tolerance and the Ethical Life. London, New York: Continuum. 
Hesse-Biber, Sh. N.; Leavy, P. 2006. Emergent Methods and Social Research. London, New Delhi: Saga Publications.

Hulswit, M. 2005. "How Causal is Downward Caustion“, Journal for General Philosophy of Science 36(2): 261-287. doi:10.1007/s10838-006-7153-3

Kanišauskas, S. 2003. Filosofija ir psichologija: Santykis ir pasaulèvaizdžio kontekstai. Vilnius: Lietuvos teisès universiteto leidykla.

Kanišauskas, S. 2008. Sinergetinio pasaulèvaizdžio kontūrai. Vilnius: Mykolo Romerio universiteto leidykla.

Laffitte, J. 2009. Ko negali toleruoti tolerancija (II) [online], [Last access: 10-06-2009]. Available from Internet: $<$ http://.bernardinai.lt/index.php?uvl=articles/88651 $>$.

Lakoff, G.; Johnson, M. 1999. Philosophy in the Flesch. New York: Basic Books.

Legutko, R. 2006. Tolerancija. Vilnius: Kronta.

MacIntosh, R.; MacLean, D.; Stacey, R.; Griffin, D. 2005. Complexity and Organization: Readings and Conversations. London, New York: Routledge.

McKinnon, C. 2006. Tolerantion: A Critical Introduction. London, New York.

Miniotaitè, G. 1988. „Kanto etikos idejos šiuolaikinèje moralės filosofijoje“, iš Degutis, A. (Sud.). I. Kanto filosofijos profiliai. Vilnius: Mintis, 152-153.

Plečkaitis, R. 1998. Tolerancija. Vilnius: Pradai.

Pyragas, K. 2003. Netiesinès dinamikos pagrindai. Vilnius: UAB „Ciklonas“.

Seppanen, J. 1998. "Systems, Ideology and Social Sciences", in Systems: New paradigms for Human Sciences. Berlin, New York: Werterde Gruynter, 180-302.

Spieß, J. 2003. Tiesa ir tolerancija [online], [Last access 07-06-2009]. Available from Internet: $<$ http://www.lksb.lt/straipsniai/straipsnis-97.htm> .

Sprindžiūnas, A. 2004. „Tolerancijos samprata“, iš Tolerancijos ugdymas mokykloje. Vilnius: Garnelis, 9-26.

United Nations Millenium Declaration. 2000 [online], [Last access: 17-02-2010]. Available from Internet: <http:www.un.org/millennium/declaration/ares552e.htm>.

Wheatley, M. J. 1999. Leadership and the New Science: Discovering Order in a Chaotic World. San-Francisco: Berrett-Koehler Publichers.

Žuravliovas, A. 1980. Tolerancija ir techniniai matavimai. Vilnius: Mokslas.

Давыдов, А. А. 1994. Модульный анализ и конструирование сочиума. Москва: Российская академия наук, Институт социологии.

Давыдов, А. А. 2006. Системная сочиология. Москва: КомКнига.

Ельчанов, М. С. 2005. Сочиальная синергетика и катастрофы России в эпоху модерна. Москва: КомКнига.

Киященко, Л. П. 2005. „Опыт философии трансдисциплинарности (казус „био-этика“)“, Вопросы философии 8: 105-117.

Мированов, В. П. 2005. Синергетика и самоорганизация: Общая и социальная психология. Москва: КомКнига.

Хиценко, В. Е. 2005. Самоорганизаиия: Элементы теории и сочиальные приложения. Москва: КомКнига. 


\title{
TOLERANCIJOS RIBOS IR KULTŪRINIS EGALITARIZMAS
}

\author{
Saulius Kanišauskas
}

\section{Santrauka}

Formalių kriterijų, kurie leistų spręsti tolerancijos paradokso problemą, svarba išryškejjo kultūrinio egalitarizmo akivaizdoje. Tokių kriterijų nėra iki šiol. Isitikinimas, kad tolerancijos problema prasminga tik socialinio ir politinio diskurso kontekste, gali būti kvestionuojamas vien todèl, kad per kelis šimtmečius ši nuostata problemos išspręsti nepadejo. Straipsnyje parodoma, kad tolerancijos problemą galima spręsti sisteminiu požiūriu ir sociosinergetikos įžvalgomis. Tolerancijai skirtos literatūros analizè leidžia daryti išvadą, kad bendriausiu atveju tolerancijos ribas nustatančiu formaliu kriterijumi galima laikyti tokius nukrypimus nuo normos (kaip idealių visuomeninès sistemos parametrų), kuriems esant ji dar gali normaliai (stabiliai) funkcionuoti. Kultūrinis egalitarizmas, reikalaujantis sulyginti daugumos ir diskriminuojamų mažumų teises, pažeidžia būtinos įvairovès proporcijas ir todèl yra kvestionuotinas.

Reikšminiai žodžiai: egalitarizmas, tolerancijos paradoksas, tolerancijos ribos, būtinos disharmonijos konstanta.

Received 22 January 2010, accepted 1 February 2010 